\title{
Occupational exposure to wood dust and formaldehyde and risk of nasal, nasopharyngeal, and lung cancer among Finnish men
}

This article was published in the following Dove Press journal:

Cancer Management and Research

4 August 2012

Number of times this article has been viewed

\section{Sie Sie Siew ${ }^{1,2}$ \\ Timo Kauppinen' \\ Pentti Kyyrönen ${ }^{3}$ \\ Pirjo Heikkilä' \\ Eero Pukkala 2,3}

'Finnish Institute of Occupational Health, Helsinki, Finland; ${ }^{2}$ School of Health Sciences, University of

Tampere, Tampere, Finland; ${ }^{3}$ Finnish Cancer Registry, Institute for Statistical and Epidemiological Cancer Research, Helsinki, Finland
Correspondence: Sie Sie Siew (Angelica Siew)

Finnish Institute of Occupational Health, Topeliuksenkatu 4I a A, FI-00250

Helsinki, Finland

Tel +358304741

$\mathrm{Fax}+3584732548$

Email angelica.ss.siew@gmail.com
Abstract: Controversy exists over whether or not occupational inhalation exposure to wood dust and/or formaldehyde increases risk for respiratory cancers. The objective of this study was to examine the risk of nasal, nasopharyngeal, and lung cancer in relation to occupational exposure to wood dust and formaldehyde among Finnish men. The cohort of all Finnish men born between the years 1906 and 1945 and in employment during 1970 was followed up through the Finnish Cancer Registry for cases of cancers of the nose $(n=292)$, nasopharynx $(n=149)$, and lung $(n=30,137)$ during the period 1971-1995. The subjects' occupations, as recorded in the population census in 1970, were converted to estimates of exposure to wood dust, formaldehyde, asbestos, and silica dust through the Finnish job-exposure matrix. Cumulative exposure (CE) was calculated based on the prevalence, average level, and estimated duration of exposure. The relative risk (RR) estimates for the CE categories of wood dust and formaldehyde were defined by Poisson regression, with adjustments made for smoking, socioeconomic status, and exposure to asbestos and/or silica dust. Men exposed to wood dust had a significant excess risk of nasal cancer overall (RR, 1.59; 95\% confidence interval [CI], 1.06-2.38), and specifically nasal squamous cell carcinoma (RR, 1.98; 95\% CI, 1.19-3.31). Workers exposed to formaldehyde had an RR of 1.18 (95\% CI, 1.12-1.25) for lung cancer. There was no indication that CE to wood dust or formaldehyde would increase the risk of nasopharyngeal cancer. Occupational exposure to wood dust appeared to increase the risk of nasal cancer but not of nasopharyngeal or lung cancer. The slight excess risk of lung cancer observed for exposure to formaldehyde may be the result of residual confounding from smoking. In summary, this study provides further evidence that exposure to wood dust in a variety of occupations may increase the risk of nasal cancer. Keywords: job-exposure matrix, inhalation exposure, cumulative exposure, cancer risk

\section{Introduction}

There is ongoing debate on whether occupational exposure to wood dust and formaldehyde increases the risk of specific respiratory cancers. ${ }^{1-3}$ Such exposures have been repeatedly linked to cancers of the nose, nasopharynx, and lung, but the carcinogenicity is not firmly established. ${ }^{4}$

In 1995 the International Agency for Research on Cancer (IARC) classified wood dust as carcinogenic to humans (ie, in the IARC category of Group 1), based on evidence of exposure to hardwood dust and the risk of adenocarcinoma of the nasal cavities and paranasal sinuses among exposed woodworkers. ${ }^{3}$ In 2009 the IARC concluded that wood dust causes cancer of the nasal cavities, paranasal sinuses, and nasopharynx. ${ }^{5}$ In Demers et al's ${ }^{6}$ pooled reanalysis there was a notation with respect 
to the wood type and histological subtype of the disease: the excess risk of nasal squamous cell carcinoma indicated for softwood dust was consistent across the cohorts but it was less than that for hardwood dust. ${ }^{5}$ Limited studies that investigated the details of tumor histology have noted substantial risks for nasal adenocarcinoma. ${ }^{5}$

The epidemiological studies published by the IARC after 1995 have shown contradictory evidence on carcinogenicity and occupational exposure to wood dust. ${ }^{4,7-11}$ Several paradoxical findings have offered opportunities for new studies to recapitulate the plausible carcinogenicity with stronger evidence, such as a much greater risk by exposure to softwood dust suggested in northern Europe than in North America, ${ }^{12}$ the conflicting dose-response pattern (strong link between nasopharyngeal cancer with low intensity and a short-duration exposure), ${ }^{6,9}$ and the uncommon evidence in lung cancer., ${ }^{4,13}$ Natural chemical substances exist in wood, wood preservatives, varnishes, plausible combined effects led by complex exposure to formaldehyde and other confounders within those revealed links. There has been a major weakness in lack of data in terms of quantitative exposure assessment and cancer cases; these data are necessary to enable adequate detection of the excess risks, and thus it is a logical presumption that previous findings could be somewhat underestimated.

Categorized by the IARC as Group 2A (probably carcinogenic to humans) in $1995,{ }^{3}$ the carcinogenicity classification of formaldehyde was shifted to Group 1 in $2006 .{ }^{14}$ This reevaluation was based on evidence from North American studies in nasopharyngeal cancer risk. Several subsequent epidemiological studies also indicated a link between formaldehyde exposure and nasopharyngeal cancer. ${ }^{11,15-17}$ Some studies have suggested the effect from possible exposures to other substances at work ${ }^{18}$ and prolonged contact with formaldehyde. ${ }^{19}$ The IARC Monograph Working Group recently reaffirmed that exposure to formaldehyde is likely to be responsible for increased risk in nasopharyngeal cancer. ${ }^{5}$

Although the suggestion of lung cancer risk is reported, ${ }^{3}$ neither wood dust nor formaldehyde has been consistently associated with an elevated risk, particularly among the population who experience the highest exposures.

Nasal cancer is a rare disease. The age-adjusted incidence among northern European men varies from 0.4 per 100,000 in Sweden and Finland to 0.8 per 100,000 in Denmark..$^{20,21}$ According to the Finnish Cancer Registry (FCR), the incidence rates of nasopharyngeal cancer, nasal squamous cell carcinoma, and nasal adenocarcinoma among Finnish men over the past 3 decades were $0.3,>0.3$, and
0.1 per 100,000, respectively; as for lung cancer, it has been the most common cancer of all time, with the incidence rate of 67 per 100,000 .

Two percent ( 62 million workers) of the global workforce is occupationally exposed to wood dust $\mathrm{t}^{22}$ and $1 \%$ is exposed to formaldehyde, estimated across a wide range of occupations, with a large fraction of wood-related occupations. ${ }^{23} \mathrm{At}$ least 2 million workers are routinely exposed to wood dust in the work milieu worldwide. ${ }^{3}$ In epidemiological research this widespread occupational exposure has increased the burden of stronger evidence as to whether this working population is a high-risk group. There is also an emerging urgency for in-depth study to further investigate the link between cancer by histological site and occupational exposures among the workers and industries involved.

The objective of this study was to identify the risk of nasal, nasopharyngeal, and lung cancer in relation to occupational exposure to wood dust and formaldehyde among Finnish men.

\section{Methods}

The study cohort consisted of all 1.2 million economically active Finnish men born between 1906 and 1945 who participated in the national population census on December 31, 1970. Data on the occupations held for the longest time during 1970 were obtained from the census records. ${ }^{24}$ The socioeconomic status of each person was determined based on the person's own occupation and education as of $1970 .{ }^{25}$ In the authors' analysis, the cohort was categorized into five socioeconomic strata: (1) higher white-collar workers; (2) clerical workers; (3) skilled, blue-collar workers; (4) unskilled workers; and (5) farmers.

The census data, maintained by Statistics Finland, were updated for vital status to allow exact person-year calculation. The cancer data were obtained from the FCR, which has a nationwide database on all cancer cases in Finland since 1953. All physicians, hospitals, and institutions that handle cancer patients and all pathological, cytological, and hematological laboratories in Finland are obligated to notify the FCR of all cancer cases diagnosed. In addition, Statistics Finland annually provides the FCR with a computerized file on death certificates in which cancer is mentioned. The data coverage in the FCR is virtually complete, and the data accuracy is high. ${ }^{26}$ Since 1967 , every inhabitant residing in Finland has been assigned a unique 11-digit personal identity code, which facilitates reliable computerized record linkages in registers throughout the country. In the present study, the incident cases of respiratory cancers diagnosed between 1971 
and 1995 among Finnish men born between 1906 and 1945 were identified from the FCR for linkage with the population census data from 1970. Cancer patients who had no record in the census ( $2.2 \%$ or 676 cases) were excluded.

The Finnish job-exposure matrix (FINJEM) was used to calculate occupational exposure estimates for the study cohort. ${ }^{27}$ The FINJEM covers major occupational exposures in Finland since 1945, and it addresses exposure by occupation and calendar time. Overall, the FINJEM provides exposure estimates for tens of chemical agents and for all occupational categories used in the census. ${ }^{27}$ Some occupations were further divided according to industry, to allow for more precise exposure estimations. The proportion of exposed persons and the mean level of exposure in each occupation were used to characterize exposure. The exposure estimates are based on exposure measurements, hazard surveys, and assessments by industrial hygienists of the Finnish Institute of Occupational Health. The smoking data (percentage of workers who were daily smokers) by occupation are also included in the FINJEM. These data were obtained from annual surveys on the health behavior of the Finnish adult population during 1978-1991. ${ }^{28}$
In the present study, exposure to wood dust is restricted to only "inhalable" airborne dusts of any tree species. Wood dust refers to dust from solid wood, including bark; fresh and dried wood dust; dust from wooden boards; dust from chemically treated wood; and unspecified wood dust. Cellulose pulp and paper dust were not included in this definition. Exposure to formaldehyde is defined as occupational inhalation exposure to formaldehyde as gas, mist, or dust or to formaldehyde on a dust carrier. Occupations with more than $5 \%$ of persons exposed to the individual agent at any time between 1945 and 1984 are considered as exposed occupations in the FINJEM. The level of exposure to wood dust is quantified in milligrams of wood dust per cubic meter of workroom air $\left(\mathrm{mg} / \mathrm{m}^{3}\right)$, and exposure to formaldehyde is quantified in parts per million (ppm) in the workroom air.

The authors calculated the occupation-specific cumulative exposure (CE) of the individual agents (ie, wood dust, formaldehyde, asbestos, and silica) for every 5-year birth cohort (from 1906-1910 until 1941-1945) and every 5-year calendar period of observation (from 1971-1975 until 1991-1995) (Figure 1). The exposure of each birth cohort was assumed to start in the year when the average age of

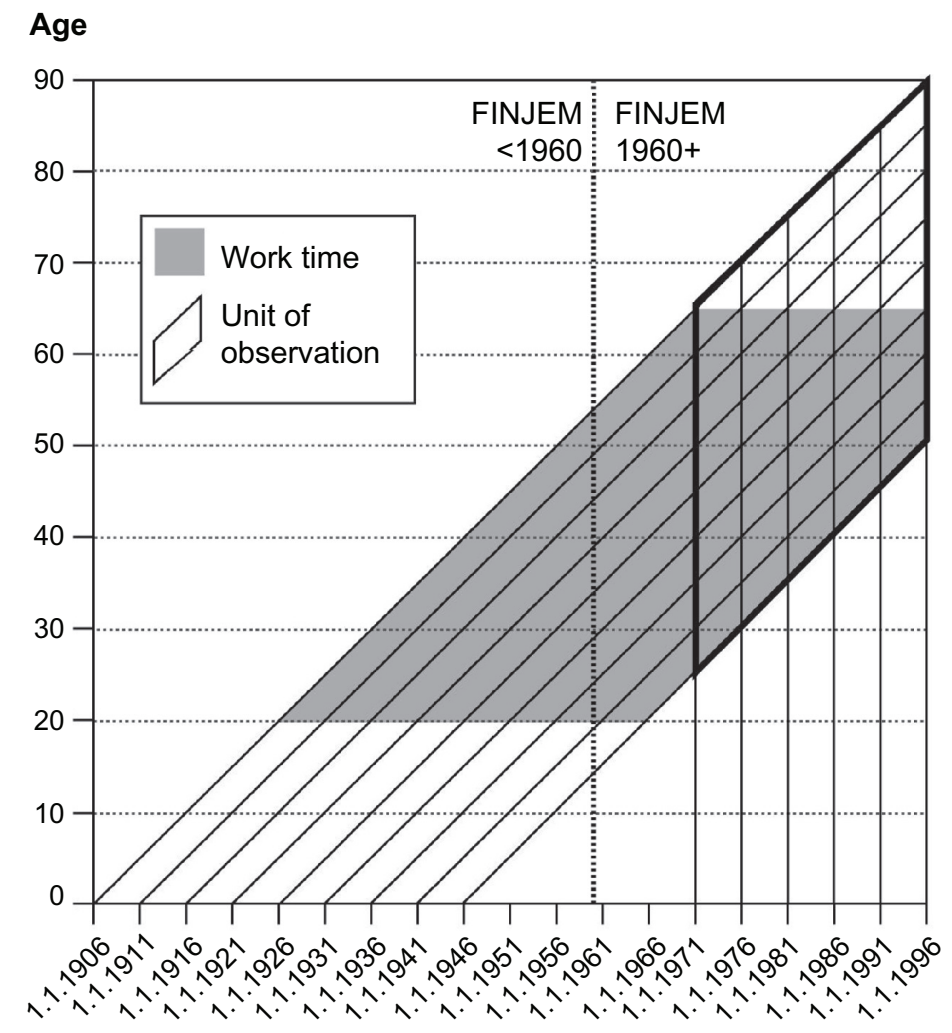

Calendar time

Figure I Units of observation, defined by birth year of the persons in the cohort (5-year birth cohorts, from 1906-1910 until 194I-1945) and calendar period of follow-up (5-year calendar periods of observation, from I97I-1975 until I99I-1995), estimated exposure period (work time), and periods in the Finnish job-exposure matrix (FINJEM) used for exposure estimation. 
the birth cohort was 20; the exposure of each birth cohort was assumed to end in the year of the midpoint during the observation period, minus 20 years (latency). For instance, to calculate the cancer risk for the observation period 1981-1985 (midpoint, 1983), only the exposures until 1963 were taken into account.

The occupational stability of Finnish workers is high. Most Finnish workers (80\%) remain in the same job for 5 or more years. ${ }^{25}$ Therefore, in the calculation of exposure duration, the authors assumed that the workers remained in the same job as recorded in the census in 1970 between the ages of 20 and 65 years. In each calendar year, two aspects were used to measure the annual average exposure: the proportion of exposed persons and the mean level of exposure for each occupation. When exposure occurred before 1960 , the authors used the FINJEM estimates for the period 1945-1959; otherwise, the FINJEM estimates for the period 1960-1984 were used (Table 1).

Table I Exposure to wood dust and formaldehyde based on the Finnish job-exposure matrix and smoking prevalence by occupation among Finnish men who were born between 1906 and 1946 and who participated in the population census in 1970

\begin{tabular}{|c|c|c|c|c|c|c|c|c|c|c|}
\hline \multirow[t]{3}{*}{ Code $^{a}$} & \multirow[t]{3}{*}{ Occupation } & \multicolumn{4}{|c|}{ Wood dust } & \multicolumn{4}{|c|}{ Formaldehyde } & \multirow{3}{*}{$\begin{array}{l}\text { Daily smoking, } \\
|978-| 99 \mid \\
(\%)\end{array}$} \\
\hline & & \multicolumn{2}{|c|}{ | 945-1959 } & \multicolumn{2}{|c|}{ | $960-1984$} & \multicolumn{2}{|c|}{ | $945-1959$} & \multicolumn{2}{|c|}{$1960-1984$} & \\
\hline & & $\mathbf{P}(\%)$ & $\mathrm{L}\left(\mathrm{mg} / \mathrm{m}^{3}\right)$ & $\mathbf{P}(\%)$ & $L\left(\mathrm{mg} / \mathrm{m}^{3}\right)$ & $\mathbf{P}(\%)$ & L (ppm) & $\mathbf{P}(\%)$ & L (ppm) & \\
\hline 0370 & Technical nursing assistants & - & - & - & - & 12 & 0.35 & 12 & 0.20 & 25 \\
\hline 3040 & Livestock breeders & - & - & - & - & - & - & 10 & 0.15 & 23 \\
\hline 3120 & Livestock workers & - & - & - & - & - & - & 10 & 0.15 & 29 \\
\hline 3400 & $\begin{array}{l}\text { Forestry and logging } \\
\text { workers }\end{array}$ & - & - & - & - & - & - & 16 & 0.05 & 38 \\
\hline 6050 & Textile finishers/dyers & - & - & - & - & - & - & 5 & 0.20 & 28 \\
\hline 6060 & Textile quality controllers & - & - & - & - & - & - & 9 & 0.10 & 28 \\
\hline 6140 & Upholsterers & 70 & 0.10 & 65 & 0.05 & - & - & - & - & 49 \\
\hline 6160 & Garment sewers & - & - & - & - & - & - & 5 & 0.10 & 49 \\
\hline 6351 & Foundry workers, iron/steel & - & - & - & - & - & - & 45 & 0.80 & 46 \\
\hline 6352 & $\begin{array}{l}\text { Foundry workers, } \\
\text { nonferrous metal }\end{array}$ & - & - & - & - & - & - & 18 & 0.90 & 46 \\
\hline 6359 & Other foundry workers & - & - & - & - & - & - & 12 & 0.70 & 46 \\
\hline 6700 & Timber workers & 60 & 0.70 & 56 & 0.70 & - & - & - & - & 33 \\
\hline 6710 & Sawmill workers & 95 & 0.80 & 95 & 0.75 & - & - & - & - & 43 \\
\hline 6720 & $\begin{array}{l}\text { Plywood, wooden board } \\
\text { makers }\end{array}$ & 70 & 1.00 & 66 & 1.00 & - & - & 40 & 0.80 & 33 \\
\hline 6731 & Floor layers & 95 & 0.20 & 95 & 0.50 & - & - & 20 & 1.00 & 37 \\
\hline 6739 & Construction carpenters & 95 & 0.20 & 95 & 0.50 & - & - & - & - & 37 \\
\hline 6740 & Boat builders etc & 90 & 0.20 & 90 & 0.20 & - & - & 30 & 0.20 & 37 \\
\hline 6750 & Bench carpenters & 95 & 1.20 & 95 & 1.10 & - & - & 10 & 0.20 & 25 \\
\hline 6760 & Cabinetmakers, joiners & 95 & 1.40 & 95 & 1.00 & - & - & 20 & 0.20 & 32 \\
\hline 6770 & $\begin{array}{l}\text { Woodworking machine } \\
\text { operators }\end{array}$ & 95 & 2.50 & 95 & 2.50 & - & - & 20 & 0.30 & 44 \\
\hline 6780 & Wooden surface finishers & 80 & 0.20 & 80 & 0.10 & - & - & 20 & 0.20 & 37 \\
\hline 6790 & Woodworkers, nec & 95 & 0.20 & 95 & 0.10 & - & - & 12 & 0.20 & 37 \\
\hline 6809 & Painters, nec & & & & & - & - & 18 & 0.80 & 43 \\
\hline 6811 & $\begin{array}{l}\text { Varnishers, lacquerers, } \\
\text { wood industry }\end{array}$ & - & - & - & - & - & - & 90 & 1.00 & 43 \\
\hline 7310 & $\begin{array}{l}\text { Cookers, furnace men } \\
\text { (chemical process) }\end{array}$ & - & - & - & - & 10 & 0.50 & 18 & 0.60 & 34 \\
\hline 7350 & $\begin{array}{l}\text { Paper/paperboard mill } \\
\text { workers }\end{array}$ & - & - & - & - & - & - & 7 & 0.50 & 37 \\
\hline 7392 & $\begin{array}{l}\text { Paint/pharmaceuticals } \\
\text { makers }\end{array}$ & - & - & - & - & - & - & 9 & 0.60 & 34 \\
\hline 7399 & Chemical workers, nec & - & - & - & - & 20 & 0.20 & 27 & 0.20 & 34 \\
\hline 7522 & Plastic product workers & - & - & - & - & 5 & 0.10 & 56 & 0.10 & 41 \\
\hline 7529 & Plastic product workers, nec & - & - & - & - & 5 & 0.10 & 56 & 0.10 & 41 \\
\hline 7570 & Paper product workers & - & - & - & - & 10 & 0.20 & 10 & 0.15 & 55 \\
\hline 8312 & Char workers, wood industry & 80 & 4.00 & 79 & 4.00 & - & - & - & - & 33 \\
\hline
\end{tabular}

Note: a Occupational code of Finnish job-exposure matrix.

Abbreviations: P, proportion of exposed persons (\%); L, level (mean) of exposure; nec, not elsewhere classified. 
The estimated levels of $\mathrm{CE}$ were divided into three categories for analysis: (1) unexposed (reference group), (2) low, and (3) high. The wood dust results in these categories were as follows: unexposed, $0.1-9.9 \mathrm{mg} / \mathrm{m}^{3}$-years (low), and $\geq 10 \mathrm{mg} / \mathrm{m}^{3}$-years (high). The formaldehyde results in these categories were as follows: unexposed, $0.1-0.9 \mathrm{ppm}-$ years (low), and $\geq 1.0$ ppm-years (high). The CEs for occupational exposure to asbestos and silica dust in models for lung cancer were categorized as follows: asbestos - unexposed, $0.1-1.9$ fibers $/ \mathrm{cm}^{3}$-years (low), and $\geq 2$ fibers $/ \mathrm{cm}^{3}$-years (high); silica dust - unexposed, $0.1-0.9 \mathrm{mg} / \mathrm{m}^{3}$-years (low), and $\geq 1.0 \mathrm{mg} / \mathrm{m}^{3}$-years (high).

\section{Statistical analysis}

The expected numbers of cases for every occupation were calculated for each 5-year birth cohort and 5-year calendar period (Figure 1) by multiplying the number of person-years in each stratum by the corresponding cancer incidence rate of the entire study cohort. The standardized incidence ratio (SIR) was defined as the ratio of the observed to the expected number of cases. The $95 \%$ confidence intervals (CIs) for each SIR were estimated assuming that the observed number of cases followed the Poisson distribution.

The exposure-response patterns were studied with the Poisson regression analysis of the stratum-specific observed numbers of cases and person-years at risk. Relative risk (RR) estimates were calculated by comparing the categories of $\mathrm{CE}$ with the unexposed category. Smoking was included in all models, and occupational co-exposures to asbestos and silica dust were included in the model for lung cancer. Wood dust and formaldehyde were mutually adjusted in all models. A 20-year latency assumption was used in all models.

\section{Results}

Finnish workers were exposed at relatively low formaldehyde levels; out of 27 occupations, only two were detected with average exposure at $1 \mathrm{ppm}$ : (1) floor layers and (2) varnishers, lacquerers in the wood industry. Among the 13 occupational groups that involved wood dust, four occupations at the highest exposure proportions (70\%-95\%) and levels $\left(1-4 \mathrm{mg} / \mathrm{m}^{3}\right)$ were in the wood-based industries (Table 1).

Construction carpenter was the only occupation with a significantly increased SIR for lung cancer among the 32 occupations with exposure to wood dust or formaldehyde (Table 2). Construction carpenters had an SIR of 1.19 (95\% CI, 1.14-1.25). There were no significantly elevated SIRs for nasal or nasopharyngeal cancer in any occupation (Table 2).
A significantly elevated RR for nasal cancer was observed for wood dust exposure (RR, 1.59; 95\% CI, 1.06-2.38); the RR did not vary by CE level (Table 3 ). Smoking was a significant cofactor in this model (RR, 1.23 per $10 \%$ increase in prevalence of smokers in the job category; 95\% CI, 1.02-1.47). Nasal squamous cell carcinoma showed excess risk associated with exposure to wood dust (RR, 1.98; $95 \%$ CI, 1.19-3.31), and the result was similar in the category of formaldehyde exposure (Table 3 ).

No associations were found between exposure to formaldehyde and any histological type of nasal cancer (Table 3). Of 22 rare nasal adenocarcinoma cases in the study population, three cases (14\%) were exposed to wood dust: a woodworker, a woodworking machine operator, and a construction carpenter. The two former occupations also had co-exposure to formaldehyde. No excess of nasopharyngeal cancer was seen among the workers who were exposed to wood dust or to formaldehyde.

The risk of lung cancer was not detected in relation to exposure to wood dust (Table 3). Workers who experienced any level of $\mathrm{CE}$ to formaldehyde were associated with a slightly elevated excess of lung cancer (RR, $1.18 ; 95 \% \mathrm{CE}$, 1.12-1.25).

In the statistical model of lung cancer, smoking was a significant cofactor (RR, 1.22 per $10 \%$ increase in prevalence of smokers in the job category; 95\% CI, 1. 20-1.24). The category of highest exposure to silica dust showed an RR of 1.39 (95\% CI, 1.16-1.65), and that of asbestos showed an RR of 1.29 (95\% CI, 1.19-1.38).

\section{Discussion}

Wood has been the preeminent renewable energy in the world throughout the centuries. Of the total wood harvested globally, 1700 million cubic meters contribute to industrial use each year. ${ }^{22}$ In Finland, the forest sector accounts for $4 \%$ of gross domestic product, and 10\% in regional terms (southeast and eastern Finland); the number of workers employed by the forest sector has stabilized at $3 \%$ of the total workforce. Formaldehyde is a ubiquitous volatile organic compound that has been widely used in various sectors for nearly a century. The largest formaldehyde-consuming industries include furniture and foundry (cast iron, steel, and nonferrous metal). The wood industry is regarded as a high user of formaldehyde-based resin and dyes, used in the production of pressed-wood products such as particleboard, plywood paneling, medium-density fiberboard, and other wooden products for flooring, furniture, and interior and exterior construction material. According to IARC, the heaviest expo- 
Table 2 Standardized incidence ratios (SIRs) a of nasal, nasopharyngeal, and lung cancer in 197I-1995 among Finnish men in occupations with exposure to wood dust or formaldehyde who were born between 1906 and 1946 and who participated in the population census 1970

\begin{tabular}{|c|c|c|c|c|c|c|c|c|c|c|}
\hline \multirow[t]{2}{*}{ Code $^{b}$} & \multirow{2}{*}{$\begin{array}{l}\text { Occupations with exposure to } \\
\text { wood dust or formaldehyde }\end{array}$} & \multicolumn{3}{|c|}{ Nasal cancer } & \multicolumn{3}{|c|}{ Nasopharyngeal cancer } & \multicolumn{3}{|c|}{ Lung cancer } \\
\hline & & Obs (n) & SIR & $95 \% \mathrm{Cl}$ & Obs (n) & SIR & $95 \% \mathrm{Cl}$ & Obs (n) & SIR & $95 \% \mathrm{Cl}$ \\
\hline 0370 & Technical nursing assistants & - & - & $0.00-256$ & - & - & $0.00-559$ & I & 0.70 & $0.02-3.88$ \\
\hline 3040 & Livestock breeders & - & - & $0.00-26.6$ & - & - & $0.00-60.3$ & 14 & 0.78 & $0.42-1.30$ \\
\hline 3120 & Livestock workers & - & - & $0.00-7.16$ & - & - & $0.00-17.8$ & 43 & 0.78 & $0.56-1.05$ \\
\hline 3400 & Forestry and logging workers & 9 & 0.70 & $0.32-1.32$ & 5 & 1.26 & $0.4 I-2.93$ & 1453 & 1.00 & $0.95-1.05$ \\
\hline 6050 & Textile finishers/dyers & 1 & 3.15 & $0.08-17.5$ & - & - & $0.00-26.0$ & 37 & 1.03 & $0.73-1.42$ \\
\hline 6060 & Textile quality controllers & - & - & $0.00-220$ & - & - & $0.00-497$ & 1 & 0.50 & $0.01-2.81$ \\
\hline 6140 & Upholsterers & - & - & $0.00-11.9$ & - & - & $0.00-21.8$ & 38 & 1.14 & $0.8 \mathrm{I}-\mathrm{I} .57$ \\
\hline 6160 & Garment sewers & - & - & $0.00-31.5$ & - & - & $0.00-64.5$ & 12 & 0.90 & $0.46-1.57$ \\
\hline 6351 & Foundry workers, iron/steel & - & - & $0.00-12.4$ & - & - & $0.00-27.4$ & 43 & 1.27 & $0.92-1.70$ \\
\hline 6352 & Foundry workers, nonferrous metal & - & - & $0.00-69.2$ & - & - & $0.00-152$ & 5 & 0.89 & $0.29-2.09$ \\
\hline 6359 & Other foundry workers & - & - & $0.00-7.18$ & - & - & $0.00-15.7$ & 73 & 1.25 & $0.98-1.57$ \\
\hline 6700 & Timber workers & 1 & 2.03 & $0.05-11.3$ & - & - & $0.00-16.6$ & 69 & 1.21 & $0.94-1.53$ \\
\hline 6710 & Sawmill workers & 6 & 2.23 & $0.82-4.85$ & I & 0.80 & $0.02-4.48$ & 279 & 0.89 & $0.79-1.00$ \\
\hline 6720 & Plywood, wooden board makers & 2 & 2.55 & $0.31-9.20$ & - & - & $0.00-10.3$ & 82 & 0.96 & $0.76-1.19$ \\
\hline 6731 & Floor layers & - & - & $0.00-152$ & - & - & $0.00-287$ & 1 & 0.42 & $0.01-2.34$ \\
\hline 6739 & Construction carpenters & 16 & 1.28 & $0.73-2.07$ & 5 & 0.91 & $0.30-2.13$ & 1885 & 1.19 & $1.14-1.25$ \\
\hline 6740 & Boat builders etc & 2 & 4.25 & $0.52-15.4$ & - & - & $0.00-15.5$ & 53 & 0.94 & $0.7 I-1.23$ \\
\hline 6750 & Bench carpenters & I & 0.85 & $0.02-4.75$ & I & 1.65 & $0.04-9.17$ & 110 & 0.80 & $0.66-0.96$ \\
\hline 6760 & Cabinetmakers, joiners & 1 & 1.25 & $0.03-6.98$ & - & - & $0.00-9.33$ & 76 & 0.84 & $0.66-1.05$ \\
\hline 6770 & Woodworking machine operators & 1 & 0.80 & $0.02-4.47$ & 1 & 1.69 & $0.04-9.43$ & 122 & 0.86 & $0.71-1.02$ \\
\hline 6780 & Wooden surface finishers & - & - & $0.00-27.3$ & - & - & $0.00-62.4$ & 21 & 1.33 & $0.83-2.04$ \\
\hline 6790 & Woodworkers, nec & 2 & 7.34 & $0.89-26.5$ & - & - & $0.00-29.1$ & 30 & 0.96 & $0.65-1.37$ \\
\hline 6809 & Painters, nec & 1 & 0.99 & $0.03-5.54$ & - & - & $0.00-8.17$ & 107 & 0.93 & $0.76-1.13$ \\
\hline 6811 & Varnishers, lacquerers, wood industry & - & - & $0.00-396$ & - & - & $0.00-740$ & - & - & $0.00-5.22$ \\
\hline 7310 & $\begin{array}{l}\text { Cookers, furnace men } \\
\text { (chemical process) }\end{array}$ & - & - & $0.00-16.0$ & - & - & $0.00-35.8$ & 35 & 1.31 & $0.91-1.83$ \\
\hline 7350 & Paper/paperboard mill workers & 1 & 0.65 & $0.02-3.64$ & 2 & 2.83 & $0.34-10.2$ & 143 & 0.91 & $0.77-1.07$ \\
\hline 7392 & Paint/pharmaceuticals makers & - & - & $0.00-22.4$ & - & - & $0.00-49.5$ & 14 & 0.75 & $0.4 I-1.26$ \\
\hline 7399 & Chemical workers, nec & - & - & $0.00-14.0$ & - & - & $0.00-30.6$ & 31 & 1.10 & $0.75-1.56$ \\
\hline 7522 & Plastic product workers & - & - & $0.00-10.9$ & - & - & $0.00-21.4$ & 31 & 0.94 & $0.64-1.34$ \\
\hline 7529 & Plastic product workers, nec & - & - & $0.00-26.1$ & - & - & $0.00-49.7$ & 15 & 1.16 & $0.65-1.92$ \\
\hline 7570 & Paper product workers & 1 & 7.39 & $0.10-21.1$ & - & - & $0.00-29.4$ & 21 & 0.80 & $0.50-1.23$ \\
\hline 8312 & Char workers, wood industry & - & - & $0.00-825$ & - & - & $0.00-2838$ & - & - & $0.00-5.21$ \\
\hline
\end{tabular}

Notes: aReference population: all Finnish men; boccupational code of Finnish job-exposure matrix.

Abbreviations: Obs, observed cases; $\mathrm{Cl}$, confidence interval; nec, not elsewhere classified.

sures to wood dust have been reported in the cabinetmaking and wooden furniture manufacturing industry, followed by the wooden board industry, with wood dust levels frequently above 5 and $1 \mathrm{mg} / \mathrm{m}^{3}$, respectively. ${ }^{3}$ The highest continuous exposures to formaldehyde (frequently above $1 \mathrm{mg} / \mathrm{m}^{3}$ ) have been measured in particleboard mills and during the varnishing of furniture and wooden floors. ${ }^{3}$ Lower exposures are widely encountered (eg, in construction carpentry). In many occupations (eg, floor layers, plywood makers, cabinetmakers and joiners) there was combined exposure to both wood dust and formaldehyde.

The American Conference of Governmental Industrial Hygienists recognizes wood dust as a confirmed human carcinogen and recommends a permissible exposure limit
(PEL) of $1 \mathrm{mg} / \mathrm{m}^{3}$ for hardwoods and $5 \mathrm{mg} / \mathrm{m}^{3}$ for softwoods, and a short-term exposure limit of $10 \mathrm{mg} / \mathrm{m}^{3}$ for softwoods. The US National Institute for Occupational Safety and Health has established a recommended exposure limit for wood dust of $1 \mathrm{mg} / \mathrm{m}^{3}$ - this covers all soft- and hardwoods except western red cedar. The US Occupational Safety and Health Act of 1970 regulates wood dust as a nuisance dust (western red cedar: PEL, $15 \mathrm{mg} / \mathrm{m}^{3}$ ); however, it strongly encourages employers to keep exposures to a minimum and to adopt the levels set by the American Conference of Governmental Industrial Hygienists. The PEL for formaldehyde in the workplace covered by the Occupational Safety and Health Act is $0.75 \mathrm{ppm}$, the standard includes a short-term exposure limit of $2 \mathrm{ppm}$. 
Table 3 Cancer of the nose, nasopharynx, and lung among Finnish men who were born between 1906 and 1946 and who participated in the population census in 1970, by cumulative exposure to wood dust and formaldehyde: number of observed cases (Obs), relative risk (RR), and 95\% confidence interval (Cl)

\begin{tabular}{|c|c|c|c|c|c|c|}
\hline \multirow[t]{2}{*}{ Cancer site } & \multicolumn{4}{|c|}{$\begin{array}{l}\text { Cumulative exposure to wood dust } \\
\text { (mg/m } \mathrm{m}^{3} \text {-years) }\end{array}$} & \multicolumn{2}{|c|}{$\begin{array}{l}\text { Cumulative exposure to } \\
\text { formaldehyde (ppm-years) }\end{array}$} \\
\hline & None & Any & $0.1-9.9$ & $\geq 10$ & None & Any \\
\hline \multicolumn{7}{|l|}{ Nose } \\
\hline Obs (n) & 260 & 32 & 21 & 11 & 275 & 17 \\
\hline $\mathrm{RR}$ & 1 & 1.59 & 1.63 & 1.57 & I & 1.11 \\
\hline $95 \% \mathrm{Cl}$ & Ref & $1.06-2.38$ & $0.85-3.11$ & $0.98-2.52$ & Ref & $0.66-1.87$ \\
\hline \multicolumn{7}{|c|}{ Nasal squamous cell carcinoma } \\
\hline Obs (n) & 146 & 21 & 14 & 7 & 158 & 9 \\
\hline $\mathrm{RR}$ & 1 & 1.98 & 1.94 & 2.06 & 1 & 0.97 \\
\hline $95 \% \mathrm{Cl}$ & Ref & $|| 9-3.3 \mid$. & $|.08-3.5|$ & $0.91-4.68$ & Ref & $0.47-2.00$ \\
\hline \multicolumn{7}{|l|}{ Nasopharynx } \\
\hline Obs (n) & 142 & 7 & - & - & 144 & 5 \\
\hline $\mathrm{RR}$ & 1 & 0.66 & - & - & 1 & 0.87 \\
\hline $95 \% \mathrm{Cl}$ & Ref & $0.30-1.45$ & - & - & Ref & $0.34-2.20$ \\
\hline \multicolumn{7}{|l|}{ Lung } \\
\hline Obs (n) & 27387 & 2750 & 1898 & 852 & 28306 & $|83|$ \\
\hline $\mathrm{RR}$ & I & 0.93 & 0.95 & 0.91 & I & 1.18 \\
\hline $95 \% \mathrm{Cl}$ & Ref & $0.87-0.98$ & $0.87-1.03$ & $0.84-0.98$ & Ref & $1.12-1.25$ \\
\hline
\end{tabular}

Notes: A 20-year latency period was assumed; all RRs were adjusted for socioeconomic status, age, period of follow-up, and smoking; RRs for wood dust were adjusted for formaldehyde exposure and vice versa; RRs for lung cancer were further adjusted for exposure to asbestos and silica dust.

Abbreviation: Ref, reference category.

\section{Nasal cancer}

Risk for nasal cancer among Finnish workers exposed to wood dust was considerably lower than the excess risks reported in Scandinavian studies, ${ }^{27,28}$ the pooled European case-control study ${ }^{6}$ and the meta-analysis of twelve casecontrol studies on sinonasal cancer, ${ }^{29}$ in which the RRs were generally between 2.0 and 2.5. The average odds ratio of nasal cancer for all wood-related occupations was 2.0 (95\% CI, 1.6-2.5) according to the IARC in $1995^{3}$ and 2.6 (95\% CI, 2.1-3.3) in a later meta-analysis for male woodworkers. ${ }^{29}$ However, the risk detected in the present study was higher than in most of the cohort studies reviewed by the IARC in 1995.,14 In Finland, conifer trees (pine and spruce) are the main components of the softwood forest (90\%-95\% nationwide coverage) although there are also some minor fractions of hardwood species like birch and other deciduous trees. The predominant wood dust exposure to softwood processing may explain why the risk is smaller than in other studies. The small excess was also likely driven by a large cluster in the cohort - the group of construction carpenters at a relatively low exposure level to wood dust.

Cancer in workers in wood-related industries has been highlighted in a recent joint epidemiological study by five Nordic countries $\left(\mathrm{N}=2.8\right.$ million cases). ${ }^{30}$ The study reported that of the 3523 male workers with an observed case of nasal cancer, $10 \%$ were woodworkers (SIR, 1.84; 95\% CI, 1.66-2.04); the next-highest percentage was $4 \%$ (137 cases), for building hands in construction work (SIR, 1.24; 95\% CI, 1.05-1.47). These results reflect the potential cancer risk associated with woodworkers in the similar Nordic population. However, the study was occupation specific and so did not provide RR estimates for the various substances of exposure such as wood dust.

Only a few studies have included details of tumor histology and have shown a substantial risk of nasal adenocarcinoma related to high levels of exposure to hardwood dust, but quantitative exposure data on wood dust has, in general, rarely been reported. The authors' result is consistent with the epidemiological evidence from studies in Nordic countries that reported a modest risk of nasal squamous cell carcinoma among woodworkers who were exposed exclusively to softwood dust, ${ }^{12}$ although the probability could be partially due to chance, as specific wood types were not distinguished in the present study. Nasal squamous cell carcinoma has been the most common (70\%) type of nasal cavity and paranasal sinus cancers.

Exposure to wood dust varies by species of wood, industrial process, chemical treatment of wood, and distance from the source. Wood itself covers an extensive range of chemical, physical, and mechanical properties (relevant to inhalable particle size); the disparity is mainly between species but could also be within a species. On the other hand, mixed exposure to more than one species of wood was very common in this study, which complicates the exposure assessment and cancer risk profile of different species of wood. 
Limited epidemiological evidence has suggested that formaldehyde causes sinonasal cancer in humans. ${ }^{14}$ The unconvincing result from the majority of studies on formaldehyde has likely been affected by potential confounders such as wood dust in co-exposure to formaldehyde and wood dust at work, for example. ${ }^{14}$ The point estimate of the RR in the present study does not significantly indicate an excess risk in nasal cancer.

Several European studies that assessed the pathogenesis aspect and were reviewed by Blot et $\mathrm{al}^{8}$ have demonstrated a plausible but inconsistent pattern as to whether exposure to wood dust elevates the risk of a benign precursor lesion, and whether a benign lesion could be a precursor to carcinoma. These studies shared some common weaknesses, such as inability to adjust for co-exposures at work, have affected the findings.

\section{Nasopharyngeal cancer}

The absence of increased risk for nasopharyngeal cancer associated with exposure to wood dust or formaldehyde was noted in the present study. Because there are only rare cases and fairly low exposure to formaldehyde in Finland compared with other industrialized countries, the detection of excess risk of nasopharyngeal cancer could be more difficult. This result was not in accordance with the recent reevaluation from the IARC in $2009^{5}$ and two previous meta-analyses, ${ }^{2,31}$ all of which suggest that formaldehyde has a causal role for cancer of the nasopharynx among workers exposed to substantial levels of formaldehyde.

There is a lack of information available to distinguish the usage of formaldehyde according to wood types in the industry. Although workers in the Finnish cohort experienced exposure to less formaldehyde in general, the circumstances of processing mixed wood have been unavoidable. Presumably, pressed-wood products containing phenol-formaldehyde resin, which is commonly used in softwood plywood, involve formaldehyde at considerably lower rates than those containing urea-formaldehyde resins, used in hardwood. The metabolite rate of the latter has been believed to be lower, which could pose a greater health risk. The resin-to-wood ratio contained in medium-density fiberboard $(80 \%-100 \%$ hardwood - maple, oak, and cherry, for example) is higher than any other urea-formaldehyde- and phenol-formaldehyde-based pressed-wood product.

\section{Lung cancer}

Lung cancer was not a suggested risk among workers exposed to wood dust in this study, and most previous studies also lack a consistent association. ${ }^{3,5,6,31}$ The increased risk of lung cancer among workers with exposure to formaldehyde is considered to be led by the residual confounding effect of smoking and of co-exposure to formaldehyde and asbestos or crystalline silica, for example. In the stratified analysis, excess risk was absent in the higher CE group ( $\geq 1.0 \mathrm{ppm}$ ). The epidemiological evidence did not support a causal role for formaldehyde in lung cancer. ${ }^{5,14,15}$ The carcinogenicity may not reach the lower airway and lungs because of the highly reactive and rapid metabolite properties, suggesting that organs without direct contact with formaldehyde do not develop neoplasia. ${ }^{15,32}$ Only $10 \%$ of inhaled formaldehyde, at the greatest extent, reaches the lower airway at resting condition in humans. ${ }^{32,33}$

\section{Discussions of the overall study}

The present study has been able to tackle the major weaknesses in previous studies, allowing follow-up of lifetime cumulative exposure from the presumed first exposure at the age of 20 to the cancer observation period in 1971-1995 (at 25 years of cancer follow-up), and to facilitate the analysis for a 20-year latency period with sufficient cancer data. The authors were able to apply mutual adjustment for wood dust and formaldehyde exposures, while controlling for occupational co-exposures and other confounders at the aggregate level. National registries are a useful, effective, practical, and cost-effective, source of data to facilitate large-scale epidemiological study. There is high accuracy and coverage of incident cancer cases, as the FCR covers more than $99 \%$ of all malignant solid tumors diagnosed in Finland. ${ }^{26}$

The current FINJEM-based method has been proven to replicate known cancer risks. ${ }^{25}$ Job stability is relatively high in most occupations in Finland, ${ }^{26}$ and therefore the cross-sectional information on occupation represents the lifelong occupational history rather comprehensively. This is especially true for older populations in which the turnover rate between occupations is low.

The smoking data (1978-1991) were to some extent too recent - in terms of the causation of the cancers diagnosed between 1971 and 1995. Fortunately, the time trends for smoking among Finnish men have been rather similar in most occupations, and it was therefore considered reasonable to use the estimates from the period 1978-1991 to represent relative differences in smoking prevalence by occupation. ${ }^{26}$ As in any study utilizing aggregate estimates instead of individual data, residual confounding may still tend to influence the RR estimates. 
The ecological fallacy that theoretically might dilute or artificially create associations in a study based on aggregated data has not been a real problem in earlier studies in which it has been possible to compare RR derived from individuallevel data and group-level data. ${ }^{30}$

\section{Conclusion}

In summary, the current study provides further evidence that exposure to wood dust in a variety of occupations may increase the risk of nasal cancer. The results for formaldehyde are inconclusive. The modest but statistically significant association between lung cancer risk and low cumulative exposure to formaldehyde may result from residual confounding of smoking or exposures to other occupational hazards that have not yet been satisfactorily investigated. The authors conclude that occupational exposure to wood dust appears to elevate the risk of nasal cancer but not of nasopharyngeal or lung cancer. Formaldehyde does not appear to increase risk in any way whatsoever. The present preliminary study also raises the issues of future quantitative individual risk assessment and histology-specific occupational cancer epidemiological study. Assessing the physical and chemical properties, the plausible domino and synergistic effects toward the cluster of complex exposures at work, the associated effect modifiers, and the histopathology of specific cell types are future challenges to further understanding of carcinogenesis as a result of exposure to wood dust and formaldehyde.

\section{Disclosure}

The authors report no conflicts of interest in this work.

\section{References}

1. Acheson ED, Cowdell RH, Rang EH. Nasal cancer in England and Wales: an occupational survey. Br J Ind Med. 1981;38(3):218-224.

2. Blair A, Saracci R, Stewart PA, Hayes RB, Shy C. Epidemiologic evidence on the relationship between formaldehyde exposure and cancer. Scand J Work Environ Health. 1990;16(6):381-393.

3. International Agency for Research on Cancer (IARC). IARC Monographs on the Evaluation of Carcinogenic Risks to Humans: Wood Dust and Formaldehyde. Vol 62. Lyon, France: IARC, World Health Organization; 1995.

4. Jayaprakash V, Natarajan KK, Moysich KB, et al. Wood dust exposure and the risk of upper aero-digestive and respiratory cancers in males. Occup Environ Med. 2008;65(10):647-654.

5. Straif K, Benbrahim-Tallaa L, Baan R, et al; for WHO International Agency for Research on Cancer Monograph Working Group. A review of human carcinogens: part C. Metals, arsenic, dusts, and fibres. Lancet Oncol. 2009;10(5):453-454.

6. Demers PA, Boffetta P, Kogevinas M, et al. Pooled reanalysis of cancer mortality among five cohorts of workers in wood-related industries. Scand J Work Environ Health. 1995;21(3):179-190.

7. Baran S, Teul I. Wood dust: an occupational hazard which increases the risk of respiratory disease. J Physiol Pharmacol. 2007;58 Suppl 5(Pt 1): $43-50$.
8. Blot WJ, Chow WH, McLaughlin JK. Wood dust and nasal cancer risk: a review of the evidence from North America. J Occup Environ Med. 1997;39(2):148-156.

9. D'Errico A, Pasian S, Baratti A, et al. A case-control study on occupational risk factors for sino-nasal cancer. Occup Environ Med. 2009;66(7):448-455.

10. Stellman SD, Demers PA, Colin D, Boffetta P. Cancer mortality and wood dust exposure among participants in the American Cancer Society Cancer Prevention Study-II (CPS-II). Am J Ind Med. 1998; 34(3):229-237.

11. Pesch B, Pierl CB, Gebel M, et al. Occupational risks for adenocarcinoma of the nasal cavity and paranasal sinuses in the German wood industry. Occup Environ Med. 2008;65(3):191-196.

12. Andersen A, Barlow L, Engeland A, Kjaerheim K, Lynge E, Pukkala E. Work-related cancer in the Nordic countries. Scand J Work Environ Health. 1999;25 Suppl 2:1-116.

13. Barcenas CH, Delclos GL, El-Zein R, Tortolero-Luna G, Whitehead LW, Spitz MR. Wood dust exposure and the association with lung cancer risk. Am J Ind Med. 2005;47(4):349-357.

14. International Agency for Research on Cancer (IARC). IARC Monographs on the Evaluation of Carcinogenic Risks to Humans: Formaldehyde, 2-Butoxyethanol and 1-tert-Butoxypropan-2-ol. Vol 88. Lyon, France: IARC, World Health Organization; 2006.

15. Bosetti C, McLaughlin JK, Tarone RE, Pira E, La Vecchia C. Formaldehyde and cancer risk: a quantitative review of cohort studies through 2006. Ann Oncol. 2008;19(1):29-43.

16. Kupczewska-Dobecka M. Assessment of carcinogenicity of formaldehyde based on the newest literature data. Med Pr. 2007; 58(6):527-539. Polish.

17. Siemiatycki J, Richardson L, Boffetta P. Occupation. In: Schottenfeld D, Fraumeni JF Jr, editors. Cancer Epidemiology and Prevention, 3rd ed. New York, NY: Oxford University Press; 2006:322-354.

18. Marsh GM, Youk AO, Buchanich JM, Erdal S, Esmen NA. Work in the metal industry and nasopharyngeal cancer mortality among formaldehyde-exposed workers. Regul Toxicol Pharmacol. 2007;48(3): 308-319.

19. Puñal-Riobóo J, Varela-Lema L, Barros-Dios JM, Juiz-Crespo MA, Ruano-Raviña A. Occupation as a risk factor for oral and pharyngeal cancer. Acta Otorrinolaringol Esp. 2010;61(5):375-383. Spanish.

20. Engholm G, Ferlay J, Christensen N, et al. NORDCAN: Cancer Incidence, Mortality, Prevalence and Prediction in the Nordic Countries [computer program]. Version 3.5. Copenhagen, Denmark: Association of the Nordic Cancer Registries, Danish Cancer Society; 2009. Available from: http://www.ancr.nu.

21. Pukkala E. Nasal cancer in the Nordic countries. In: Wallin H, editor. Wood Dust Symposium 15th April 2004, Copenhagen, Denmark: Proceedings. Copenhagen: National Institute of Occupational Health; 2004:10.

22. Kauppinen T, Toikkanen J, Pedersen D, et al. Occupational exposure to carcinogens in the European Union. Occup Environ Med. 2000; 57(1):10-18.

23. Kauppinen T, Vincent R, Liukkonen T, et al. Occupational exposure to inhalable wood dust in the member states of the European Union. Ann Occup Hyg. 2006;50(6):549-561.

24. Central Statistical Office of Finland. Population Census 1970: Occupation and Social Position. Helsinki: Central Statistical Office of Finland; 1974.

25. Pukkala E, Guo J, Kyyrönen P, Lindbohm ML, Sallmén M, Kauppinen T. National job-exposure matrix in analyses of census-based estimates of occupational cancer risk. Scand J Work Environ Health. 2005;31(2):97-107.

26. Teppo L, Pukkala E, Lehtonen M. Data quality and quality control of a population-based cancer registry: experience in Finland. Acta Oncol. 1994;33(4):365-369.

27. Kauppinen T, Toikkanen J, Pukkala E. From cross-tabulations to multipurpose exposure information systems: a new job-exposure matrix. Am J Ind Med. 1998;33(4):409-417. 
28. Berg MA, Peltoniemi J, Puska P. Health Behaviour among the Finnish Adult Population. Helsinki: Finnish National Public Health Institute; 1992.

29. Gordon I, Boffetta P, Demers PA. A case study comparing a meta-analysis and a pooled analysis of studies of sinonasal cancer among wood workers. Epidemiology. 1998;9(5):518-524.

30. Pukkala E, Martinsen JI, Lynge E, et al. Occupation and cancer: follow-up of 15 million people in five Nordic countries. Acta Oncol. 2009;48(5):646-790.
31. Partanen T. Formaldehyde exposure and respiratory cancer: a metaanalysis of the epidemiologic evidence. Scand J Work Environ Health. 1993;19(1):8-15.

32. Nielsen GD, Wolkoff P. Cancer effects of formaldehyde: a proposal for an indoor air guideline value. Arch Toxicol. 2010;84(6):423-446.

33. Garcia GJ, Schroeter JD, Segal RA, Stanek J, Foureman GL, Kimbell JS. Dosimetry of nasal uptake of water-soluble and reactive gases: a first study of interhuman variability. Inhal Toxicol. 2009;21(7): 607-618.

\section{Publish your work in this journal}

Cancer Management and Research is an international, peer-reviewed open access journal focusing on cancer research and the optimal use of preventative and integrated treatment interventions to achieve improved outcomes, enhanced survival and quality of life for the cancer patient. The journal welcomes original research, clinical \& epidemiological studies, reviews \& evaluations, guidelines, expert opinion \& commentary, case reports \& extended reports. The manuscript management system is completely online and includes a very quick and fair peerreview system, which is all easy to use. Visit http://www.dovepress.com/ testimonials.php to read real quotes from published authors.

Submit your manuscript here: http://www.dovepress.com/cancer-management-and-research-journal 